\title{
Influence of humidity, rainfall, and fipronil toxicity on rice leaffolder (Cnaphalocrocis medinalis)
}

\author{
Jakarpong Supawan, Wiboon Chongrattanameteekul* \\ Department of Entomology, Faculty of Agriculture, Kasetsart University, Bangkok 10900 Thailand \\ *Corresponding author, e-mail: wiboon.c@ku.ac.th
}

Received 3 Jun 2016

Accepted 16 Jun 2017

\begin{abstract}
The relationship between weather and rice leaffolder population in Kamphaeng Phet and Phichit provinces, Thailand from February 2013 to February 2014 was evaluated. The results showed that the numbers of rice leaffolder larvae were significantly correlated with maximum temperature $(r=0.474)$ and average temperature $(r=0.375$ ). Increasing temperature within the upper threshold of the species generally promoted insect population growth. Although statistically non-significant, relative humidity and rainfall produced negative correlation with rice leaffolder population ( $r=-0.249$ and -0.091 , respectively). Both factors might reduce leaffolder population via promoting activity of microbial control agents and physically dislodging eggs and larvae of rice leaffolder. When the insecticide fipronil was tested against populations of rice leaffolder in conventional and organic paddy fields, the lethal concentration $\left(\mathrm{LC}_{50}\right)$ value from toxicity tests with a population from a conventional field was significantly higher than with that of the organic field (63.3 versus $51.1 \mathrm{ppm}$ ). With continued and prolonged use of fipronil in a rice field, there is a tendency of that rice leaffolder to develop resistance to this insecticide. Resistance management and resistance monitoring should to be seriously considered if effective control is desired.
\end{abstract}

KEYWORDS: weather components, rice leaffolder, organic rice

\section{INTRODUCTION}

Rice (Oryza sativa), the staple diet of more than half of the world's population, is grown over 120 million hectares to produce 600 million tons of grain with an average productivity of $3.4 \mathrm{Mt} / \mathrm{ha}^{1}$. The world rice crop is attacked by more than 100 species of insects; 20 of them can cause economic damage during the different stages of the crop. Insect pests that can cause significant yield losses are stem borers, leafhoppers and planthoppers (which cause direct damage by feeding as well as by transmitting viruses), gall midges (a group of defoliating species, mainly lepidopterans), and a grain-sucking bug complex ${ }^{2,3}$.

The rice leaffolder (RLF), Cnaphalocrocis medinalis (Guenee), was considered a minor pest of rice, but it has become increasingly important with the spread of high-yielding rice varieties and the accompanying changes in cultural practices ${ }^{4}$. Serious outbreaks of RLF have been reported in many Asian countries including India, Korea, Japan, China, Malaysia, Sri Lanka, Thailand, and Vietnam ${ }^{5,6}$. The larvae feed by scraping the green mesophyll tissues from rice leaves, thus producing areas of damage appearing as linear, pale white stripes. The damaged leaves serve as entry points for fungal and bacterial infections ${ }^{7}$.

Temperature is an important abiotic factor that regulates the development, phenology, and population dynamics of insects. Understanding the relationship between temperature and the developmental rate of a target pest is important in predicting the seasonal occurrence of the species and to establish environment-friendly pest management strategies ${ }^{8}$. Management of RLF using synthetic chemicals has failed because of insecticide resistance, pesticide residues in food, pest resurgence, toxic effects on human beings, and environmental pollution ${ }^{9,10}$. This study investigates the relationship between RLF population and weather components in lower northern Thailand and the toxicity of the insecticide fipronil in order to provide information for effective pest management strategy for this insect in the region.

\section{MATERIALS AND METHODS}

\section{Field experiment}

The experiments were conducted in the paddy fields at Kamphaeng Phet and Phichit provinces, Thailand during 3 cropping seasons between 2013 and 2014. 
The first crop (January-April 2013) and the second crop (May-August 2013) of both locations were grown approximately at the same period. However, the third crop in Kamphaeng Phet province was grown during November 2013 to February 2014, and the third crop in Phichit province was grown during August-November 2013. Each location consisted of 3 plots (replications) within the same vicinity with plot size of $40 \mathrm{~m} \times 40 \mathrm{~m}$. Field observations were recorded once every 2 weeks, starting from approximately 30 days after transplanting until harvest. The observations were taken by counting the total number of larvae from rice plants within a quadrat $(0.5 \mathrm{~m} \times 0.5 \mathrm{~m})$ using line transects method. Rice plants from 5 quadrats (spots) were observed on each diagonal line of each plot. The average population per quadrat was calculated.

Weather data including maximum temperature, minimum temperature, average temperature, relative humidity, and amount of rainfall from the nearest weather stations were obtained from the Thai meteorological department. All weather parameters except rainfall were averaged from weather data within 14 days prior to the specified insect sampling dates. For rainfall, the values were accumulative rainfall of 14 days prior to the specified sampling dates. The effects of weather components on RLF population were calculated by Spearman's correlation coefficient.

\section{Mass rearing of RLF in the laboratory}

The experiment was conducted on 'Phitsanulok 2' rice variety. Rice seeds were sown in plastic trays $(30 \mathrm{~cm} \times 40 \mathrm{~cm}$ ) in the greenhouse. The 20 days old seedlings were transferred into pots and prepared for rearing the rice leaffolder. The adult RLFs were collected from conventional and organic rice fields in Kamphaeng Phet province. Adults from different locations were separated into cages kept in the shade of a screened and roofed insectary and allowed to complete development. Adults were fed with honey solution following the techniques by Waldbauer and Marciano ${ }^{11}$. The third-instar larvae were collected from rice leaves to Petri dishes for insecticide resistance testing.

\section{Fipronil toxicity against RLF larvae}

Different concentrations of fipronil 5\% SC were prepared from commercial formulation. The insecticide was diluted with distilled water to prepare a range of concentrations from $0,20,40,60,80$, and $100 \mathrm{ppm}$. The rice leaves were treated by dipping with different concentrations of insecticide.
Untreated control leaves were treated with distilled water. The leaves cut were allowed to dry at room temperature for $10 \mathrm{~min}$ and then placed in $15 \mathrm{~cm}$ diameter Petri dishes with moistened paper. Ten third-instar larvae were placed on the treated leaves and kept in environmental chambers at $25 \pm 1{ }^{\circ} \mathrm{C}, 70 \pm 10 \% \mathrm{RH}$. Each treatment was replicated 3 times. The larvae which did not respond to pencil tip prodding were considered dead. Mortality was recorded at $24 \mathrm{~h}$ after the treatment.

\section{Statistical analysis}

Mortality data were subject to analysis using dosemortality regression. The $\mathrm{LC}_{50}$ and $\mathrm{LC}_{90}$ values were computed by probit analysis ${ }^{12}$ with corrected mortality using Abbott's formula ${ }^{13}$. The $\mathrm{LC}_{50}$ values obtained from conventional and organic rice fields were compared by independent sample $t$-test.

\section{RESULTS}

\section{Relationship between weather components and RLF population}

The correlations of weather components and larval population of RLF are shown in Table 1. The results showed that the number of RLF larvae in the field had significant positive correlation with maximum temperature and average temperature $(r=0.474$ and 0.375 , respectively). Although other weather parameters including minimum temperature, relative humidity, and rainfall did not show significant results $(p>0.05)$, it should be noted that both relative humidity and rainfall produced a negative correlation with the number of RLF larvae ( $r=$ -0.249 and -0.091 , respectively).

\section{Toxicity of fipronil against RLF larvae}

Laboratory tests to evaluate the $\mathrm{LC}_{50}$ and $\mathrm{LC}_{90}$ values of insecticide fipronil against RLF were performed using insect populations from conventional and organic rice fields. The results showed that the regression lines fitted very well with the mortality data with the coefficient of determination $\left(R^{2}\right)$ ranging between 0.81 and 0.96 (Tables 2 and 3). The progenies of leaffolder collected from conventional field had higher $\mathrm{LC}_{50}$ and $\mathrm{LC}_{90}$ values in all 3 tests conducted. The $\mathrm{LC}_{50}$ values from the $1 \mathrm{st}$, 2nd, and 3rd tests were 64.7, 60.1, and $65.2 \mathrm{ppm}$, respectively (Table 2), while those from the organic field were 52.0, 50.6, and $50.7 \mathrm{ppm}$, respectively (Table 3). Similarly, the $\mathrm{LC}_{90}$ of the 1 st, 2 nd, and 3rd tests from conventional field were also higher 
Table 1 Correlation of weather components and mean number of $C$. medinalis.

\begin{tabular}{|c|c|c|c|c|c|c|c|}
\hline \multirow{2}{*}{$\begin{array}{l}\text { Observation } \\
\text { date }\end{array}$} & \multirow[t]{2}{*}{ Location } & \multicolumn{5}{|c|}{ Weather components ${ }^{\dagger}$} & \multirow{2}{*}{$\begin{array}{l}\text { Mean no. of RLF } \\
\text { larvae per } 0.25 \mathrm{~m}^{2} \\
\text { quadrat }\end{array}$} \\
\hline & & $\begin{array}{l}\text { Maximum } \\
\text { temp. }\left({ }^{\circ} \mathrm{C}\right)\end{array}$ & $\begin{array}{l}\text { Minimum } \\
\text { temp. }\left({ }^{\circ} \mathrm{C}\right)\end{array}$ & $\begin{array}{l}\text { Average } \\
\text { temp. }\left({ }^{\circ} \mathrm{C}\right)\end{array}$ & $\begin{array}{c}\text { Relative } \\
\text { humidity (\%) }\end{array}$ & $\begin{array}{l}\text { Rainfall } \\
\text { (mm) }\end{array}$ & \\
\hline $26 / 2 / 2013$ & $\begin{array}{l}\text { Kamphaeng Phet } \\
\text { Phichit }\end{array}$ & $\begin{array}{l}35.0 \\
34.3\end{array}$ & $\begin{array}{l}22.4 \\
22.3\end{array}$ & $\begin{array}{l}28.3 \\
28.2\end{array}$ & $\begin{array}{l}67.8 \\
73.9\end{array}$ & $\begin{array}{c}1.6 \\
0\end{array}$ & $\begin{array}{c}0.43 \\
0\end{array}$ \\
\hline $12 / 3 / 2013$ & $\begin{array}{l}\text { Kamphaeng Phet } \\
\text { Phichit }\end{array}$ & $\begin{array}{l}34.9 \\
33.3\end{array}$ & $\begin{array}{l}23.1 \\
22.5\end{array}$ & $\begin{array}{l}28.4 \\
28.0\end{array}$ & $\begin{array}{l}70.5 \\
76.7\end{array}$ & $\begin{array}{l}24.8 \\
55.6\end{array}$ & $\begin{array}{l}0.67 \\
0.33\end{array}$ \\
\hline $26 / 3 / 2013$ & $\begin{array}{l}\text { Kamphaeng Phet } \\
\text { Phichit }\end{array}$ & $\begin{array}{l}37.5 \\
35.5\end{array}$ & $\begin{array}{l}21.5 \\
22.7\end{array}$ & $\begin{array}{l}29.4 \\
29.1\end{array}$ & $\begin{array}{l}59.3 \\
72.8\end{array}$ & $\begin{array}{l}0 \\
0\end{array}$ & $\begin{array}{l}0.33 \\
0.07\end{array}$ \\
\hline $11 / 4 / 2013$ & $\begin{array}{l}\text { Kamphaeng Phet } \\
\text { Phichit }\end{array}$ & $\begin{array}{l}38.6 \\
37.2\end{array}$ & $\begin{array}{l}24.7 \\
23.5\end{array}$ & $\begin{array}{l}31.5 \\
30.6\end{array}$ & $\begin{array}{l}60.8 \\
66.1\end{array}$ & $\begin{array}{l}0 \\
0\end{array}$ & $\begin{array}{l}1.70 \\
1.40\end{array}$ \\
\hline $8 / 6 / 2013$ & $\begin{array}{l}\text { Kamphaeng Phet } \\
\text { Phichit }\end{array}$ & $\begin{array}{l}34.8 \\
35.2\end{array}$ & $\begin{array}{l}25.1 \\
23.2\end{array}$ & $\begin{array}{l}29.1 \\
29.5\end{array}$ & $\begin{array}{l}78.8 \\
74.2\end{array}$ & $\begin{array}{c}121.7 \\
62.2\end{array}$ & $\begin{array}{l}0 \\
0\end{array}$ \\
\hline $21 / 6 / 2013$ & $\begin{array}{l}\text { Kamphaeng Phet } \\
\text { Phichit }\end{array}$ & $\begin{array}{l}33.3 \\
33.5\end{array}$ & $\begin{array}{l}25.2 \\
22.2\end{array}$ & $\begin{array}{l}28.6 \\
28.6\end{array}$ & $\begin{array}{l}82.8 \\
82.1\end{array}$ & $\begin{array}{c}93.9 \\
240.1\end{array}$ & $\begin{array}{l}0.40 \\
0.23\end{array}$ \\
\hline $5 / 7 / 2013$ & $\begin{array}{l}\text { Kamphaeng Phet } \\
\text { Phichit }\end{array}$ & $\begin{array}{l}32.7 \\
32.9\end{array}$ & $\begin{array}{l}25.1 \\
23.8\end{array}$ & $\begin{array}{l}28.3 \\
28.7\end{array}$ & $\begin{array}{l}82.4 \\
82.3\end{array}$ & $\begin{array}{l}40.6 \\
51.6\end{array}$ & $\begin{array}{l}0 \\
0\end{array}$ \\
\hline $18 / 7 / 2013$ & $\begin{array}{l}\text { Kamphaeng Phet } \\
\text { Phichit }\end{array}$ & $\begin{array}{l}32.6 \\
32.4\end{array}$ & $\begin{array}{l}24.6 \\
23.2\end{array}$ & $\begin{array}{l}28.0 \\
27.9\end{array}$ & $\begin{array}{l}82.6 \\
83.9\end{array}$ & $\begin{array}{c}135.4 \\
93.8\end{array}$ & $\begin{array}{l}0.13 \\
0.20\end{array}$ \\
\hline $1 / 8 / 2013$ & $\begin{array}{l}\text { Kamphaeng Phet } \\
\text { Phichit }\end{array}$ & $\begin{array}{l}31.3 \\
31.2\end{array}$ & $\begin{array}{l}24.8 \\
23.0\end{array}$ & $\begin{array}{l}27.2 \\
27.5\end{array}$ & $\begin{array}{l}86.6 \\
86.8\end{array}$ & $\begin{array}{l}96.7 \\
43.6\end{array}$ & $\begin{array}{c}0 \\
0.17\end{array}$ \\
\hline $1 / 10 / 2013$ & Phichit & 30.6 & 23.4 & 27.1 & 87.7 & 179.2 & 0.07 \\
\hline $16 / 10 / 2013$ & Phichit & 33.1 & 23.4 & 29.1 & 76.8 & 9.0 & 0.03 \\
\hline $31 / 10 / 2013$ & Phichit & 31.5 & 24.0 & 27.4 & 82.3 & 52.2 & 0.03 \\
\hline $16 / 11 / 2013$ & Phichit & 32.8 & 23.4 & 28.0 & 76.5 & 52.2 & 1.77 \\
\hline $28 / 11 / 2013$ & Phichit & 31.2 & 23.5 & 27.6 & 78.7 & 0.9 & 3.70 \\
\hline $15 / 12 / 2013$ & Kamphaeng Phet & 30.3 & 19.4 & 24.2 & 76.2 & 2.7 & 0 \\
\hline $2 / 1 / 2014$ & Kamphaeng Phet & 27.0 & 14.4 & 20.0 & 74.3 & 0 & 0 \\
\hline $17 / 1 / 2014$ & Kamphaeng Phet & 30.4 & 18.1 & 23.7 & 71.9 & 0 & 0 \\
\hline $30 / 1 / 2014$ & Kamphaeng Phet & 28.9 & 14.0 & 20.9 & 67.3 & 0 & 0 \\
\hline $16 / 2 / 2014$ & Kamphaeng Phet & 33.6 & 19.7 & 26.2 & 65.2 & 0 & 0.10 \\
\hline $\begin{array}{l}\text { Spearman's corr. } \\
p \text {-value }\end{array}$ & & $\begin{array}{l}0.474 \\
0.011^{*}\end{array}$ & $\begin{array}{l}0.164 \\
0.405\end{array}$ & $\begin{array}{l}0.375 \\
0.050^{*}\end{array}$ & $\begin{array}{c}-0.249 \\
0.200\end{array}$ & $\begin{array}{c}-0.091 \\
0.645\end{array}$ & \\
\hline
\end{tabular}

${ }^{\dagger}$ Maximum temperature, minimum temperature, average temperature, and relative humidity were averaged from data within 14 days prior to insect sampling date; rainfall data were cumulative rainfall within 14 days prior to insect sampling date.

* Spearman's correlation coefficient between weather components and mean number of RLF larvae recorded within the date.

* Significant at $\alpha=0.05$.

with the values of $125.3,112.2$, and $114.6 \mathrm{ppm}$, respectively, as compared to $94.6,87.9$, and $95.1 \mathrm{ppm}$, respectively, for those from the organic field. The higher lethal concentration values indicated that the population of RLF from the conventional field could tolerate higher concentrations of fipronil. This may be the result of selection pressure from applying insecticides including fipronil which had been imposed on the RLF population. Although the recommendation rate for RLF control in Thailand (equivalent to $125 \mathrm{ppm}$ ) is roughly the same as the $\mathrm{LC}_{90}$ value and is still effective, there is a tendency that continued application of fipronil may cause resistance development in RLF.

When the $\mathrm{LC}_{50}$ values obtained from RLF population collected from conventional field were compared with those from organic field using independent sample $t$-test, the result was statistically significant with $p=0.001$ (mean difference: 12.256; standard error of the difference: 1.698; lower: 7.542; 
Table 2 Lethal concentration (LC) and regression parameter estimates of fipronil tested against RLF collected from conventional rice field at $24 \mathrm{~h}$ after treatment.

\begin{tabular}{lccc}
\hline Treated/Parameter* & 1st test & 2nd test & 3rd test \\
\hline $\mathrm{LC}_{50}(\mathrm{ppm})^{\dagger}$ & 64.7 & 60.1 & 65.2 \\
${\text { Range of } \mathrm{LC}_{50}}^{\dagger}$ & $55.2-76.2$ & $36.8-89.6$ & $48.7-86.9$ \\
$\mathrm{LC}_{90}(\mathrm{ppm})^{\dagger}$ & 125.3 & 112.2 & 114.6 \\
Range of $\mathrm{LC}_{90}$ & $106.9-158.3$ & $84.9-223.0$ & $91.3-182.1$ \\
$A$ & -1.370 & -1.478 & -1.689 \\
$B$ (slope) & 0.021 & 0.025 & 0.026 \\
$R^{2}$ & 0.91 & 0.81 & 0.87 \\
\hline${ }^{\dagger} \mathrm{LC}_{50}$ and $\mathrm{LC}_{90}$ are the lethal concentrations $(\mathrm{ppm})$ \\
\multicolumn{4}{l}{ that kill 50\% and 90\%, respectively, of RLF from the } \\
average of three replications. \\
* Parameter estimates for regression line $Y=A+B X$.
\end{tabular}

Table 3 Lethal concentration (LC) and regression parameter estimates of fipronil tested against RLF.

\begin{tabular}{lccc}
\hline Treated/Parameter & 1st test & 2nd test & 3rd test \\
\hline $\mathrm{LC}_{50}(\mathrm{ppm})^{\dagger}$ & 52.0 & 50.6 & 50.7 \\
Range of LC50 $^{\dagger}$ & $35.0-68.9$ & $43.7-57.3$ & $42.9-58.3$ \\
$\mathrm{LC}_{90}(\mathrm{ppm})^{\dagger}$ & 94.6 & 87.9 & 95.1 \\
Range of $\mathrm{LC}_{90}$ & $75.8-143.0$ & $78.5-101.7$ & $84.0-112.3$ \\
$A$ & -1.796 & -1.736 & -1.459 \\
$B$ (slope) & 0.023 & 0.034 & 0.029 \\
$R^{2}$ & 0.91 & 0.94 & 0.96 \\
\hline
\end{tabular}

${ }^{\dagger} \mathrm{LC}_{50}$ and $\mathrm{LC}_{90}$ are the lethal concentrations (ppm) that kill $50 \%$ and $90 \%$, respectively, of RLF from the average of three replications.

* Parameter estimates for regression line $Y=A+B X$.

upper: $16.969 ; t: 7.219$; degrees of freedom: 4; significat differences at the $5 \%$ level (1-tailed): $0.001)$. This result confirmed that population of RLF from the conventional rice field was more resistant to fipronil than the population from the organic rice field.

\section{DISCUSSION}

\section{Weather components and insect population}

An insect population always fluctuates according to the dynamic condition of its environment. Abiotic and biotic factors are believed to be responsible for the population change ${ }^{14}$. Weather components such as temperature, rainfall, and relative humidity have known to greatly influence the insect population directly by limiting or expanding their distribution, growth, reproduction, diapause, dispersal, and indirectly through plant mechanisms and natural enemies that regulate the insect population ${ }^{15-19}$. The seasonal effects of weather and ongoing changes in climatic conditions will directly lead to modifications in dispersal and development of insect species. The changes in surrounding temperature regimes certainly alter developmental rates and survival of insects, and subsequently act upon size and density of the population ${ }^{20}$.

With respect to the survival of the different stages of the RLF, $C$. medinalis was greatly affected at $35^{\circ} \mathrm{C}$ and the upper temperature threshold for the survival of this species appears to lie between $30^{\circ} \mathrm{C}$ and $35^{\circ} \mathrm{C}$, with the outbreak usually following a prolonged drought ${ }^{19,21}$. The significant positive correlations between larval population and maximum and average temperatures in this study (Table 1) correspond with the report that the temperatures within daily minimum temperature of $15^{\circ} \mathrm{C}$ and maximum temperatures of $39^{\circ} \mathrm{C}$ within rice growing season can affect distribution, developmental rate, and phenology of rice insect pests ${ }^{19}$. The results also agree with the reports ${ }^{3,22,23}$ which indicated that maximum temperature, minimum temperature and sunshine hours had significant positive correlation with larval population of RLF. However, few reports showed that the maximum temperature did not affect the infestation level significantly whereas the minimum temperature showed a significant and negative correlation with larval population ${ }^{24}$.

Insect abundance is certainly linked to seasonal variations in rainfall, with some species being more abundant in the dry season, whereas others proliferate only during the rains. This is generally due to direct effects of rain on insects, and indirect effects mediated through plant quality and the efficacy of natural enemies affected by rainfall ${ }^{25}$. Although non-significant, the negative correlation between RLF population and rainfall and relative humidity $(r=-0.091$ and -0.249$)$ in the present study indicate that increased rainfall and humidity might reduce the population of RLF. This observation is supported by previous studies ${ }^{24,26}$. The explanation for negative effects of rainfall and humidity is probably related to the increased virulence of microbial control agents under high humidity and physical dislodging of eggs or larvae from rice or host plant by heavy rainfall ${ }^{19,27}$.

\section{Toxicity of fipronil against rice insect pest}

Fipronil is highly toxic to both piercing-sucking and chewing insects and has been shown to possess excellent activity against a broad spectrum of insect order. However, due to the increased frequency and years of use, fipronil resistance started to appear in insects ${ }^{28,29}$. Many studies reported fipronil re- 
sistance in various insect pests such as rice stem borer, house fly, and diamondback moth ${ }^{29-32}$. In this study we found that the average $\mathrm{LC}_{50}$ values from toxicity tests of fipronil against RLF population collected from conventional paddy field was $63.3 \mathrm{ppm}$ (Table 2), which is comparable to that of a previous study in Sri Lanka in 2001 that reported the $\mathrm{LC}_{50}$ values of $60 \mathrm{ppm}$ for the same insect and insecticide ${ }^{33}$. When comparing the $\mathrm{LC}_{50}$ values of fipronil between populations of RLF from organic and conventional paddy field, the result showed that the average $\mathrm{LC}_{50}$ value from the tests with population from organic paddy field was significantly lower (51.1 ppm, Table 3). This result is in accordance with a previous study in China in $2005^{29}$ about fipronil resistance in rice stem borer. They found that rice stem borers from location with frequent insecticide application were more resistant to fipronil than the susceptible strain (reared under laboratory condition without any contact to insecticide). The higher $\mathrm{LC}_{50}$ in RLF population from conventional field indicated the tendency of fipronil resistance and might be the result from RLF and rice stem borer control during the early growth stage of rice. Overuse and frequent exposure to insecticides is often a precursor to the development of insecticide resistance ${ }^{34}$. Thus fipronil resistance monitoring should be conducted regularly in order to maintain appropriate and effective use of this insecticide.

Acknowledgements: The authors wish to express their gratitude to Seksan Homchan, Prapanpong Maifoei, and Anuwat Boonyong for generous assistance in carrying out the experiments and friendship during this study. This study was supported by the International Publication Fund allocated through the Graduate School of Kasetsart University, Thailand.

\section{REFERENCES}

1. Anonymous (2004) The Hindu Survey of Indian Agriculture, Tamil Nadu, India.

2. Pathak MD, Khan ZR (1994) Insect Pests of Rice, International Rice Research Institute, Manila, Philippines.

3. Patel HN, Kadu RV, Landge SA (2011) Study on seasonal incidence of rice leaf folders (Cnaphalocrocis medinalis Guen. and Pelopidas mathias $\mathrm{Fb}$.) of paddy and its correlation with weather parameters. Int $J$ Plant Protect 4, 175-80.

4. Loevinsohn ME, Bandong JP, Alviola AA, Litsinger JA (1993) Asynchrony of cultivation on among Philippine rice farming: causes and prospects for change. Agr Syst 41, 419-39.

5. Senthil NS, Kalaivani K, Murugan K (2006) Effect of biopesticides on the lactate dehydrogenase (LDH) of the rice leaffolder, Cnaphalocrocis medinalis (Guenee) (Insecta: Lepidoptera: Pyralidae). Ecotoxicol Environ Saf 65, 102-7.

6. Senthil NS, Chung DG, Murugan K (2004) Effect of botanicals and bacterial toxin on the gut enzyme of Cnaphalocrocis medinalis. Phytoparasitica 32, 433-43.

7. Park HH, Ahn JJ, Park CG (2014) Temperaturedependent development of Cnaphalocrocis medinalis Guenee (Lepidoptera: pyralidae) and their validation in semi-field condition. J Asia Pac Entomol 17, 83-91.

8. Dale D (1994) Insect pests of rice plant-their biology and ecology. In: Heinrich EA (ed) Biological and Management of Rice Insects, Wiley Eastern, New York, pp 363-485.

9. Youn YN, Seo MJ, Shin JG, Jang C, Yu YM (2003) Toxicity of greenhouse pesticides to multicolored Asian lady beetles, Harmonia axyridis (Coleoptera: Coccinellidae). Biol Contr 28, 164-70.

10. Covaci A, Gheorghe A, Schepens P (2004) Distribution of organochlorine pesticides, polychlorinated biphenyls and $\alpha-\mathrm{HCH}$ enantiomers in pork tissues. Chemosphere 56, 757-66.

11. Waldbauer GP, Marciano AP (1979) Mass rearing of the rice leaf folder, Cnaphalocrocis medinalis Guenée (Lepidoptera: Pyralidae) under green-house conditions. $J$ Entomol Res 3, 1-8.

12. Finney DJ (1971) Probit Analysis, Cambridge Univ Press, Cambridge.

13. Abbott WS (1925) A method of computing the effectiveness of an insecticide. $J$ Econ Entomol 18, 265-7.

14. Win SS, Muhamad R, Ahmad ZAM, Adam NA (2011) Population fluctuations of brown plant hopper Nilapavarta lugens Stal. and white backed plant hopper Sogatella furcifera Horvath on rice. J Entomol 8, 183-90.

15. Muhamad R, Chung GF (1993) The relationship between population fluctuations of Helopeltis theivora Waterhouse, availability of cocoa pods and rainfall pattern. Pertanika J Trop Agr Sci 16, 81-6.

16. Way MJ, Heong KL (1994) The role of biodiversity in the dynamics and management of insect pests of tropical irrigated rice-a review. Bull Entomol Res 84, 567-87.

17. Heong KL, Manza A, Catindig J, Villareal S, Jacobsen $\mathrm{T}$ (2007) Changes in pesticide use and arthropod biodiversity in the IRRI research farm. Outlooks Pest Manag 18, 229-33.

18. Siswanto MR, Dzolkhifli O, Elna K (2008) Population fluctuation of Helopeltis antoni Signoret on cashew Anacarcium occidentalle L., in Java Indonesia. Pertanika J Trop Agr Sci 31, 191-6.

19. Moshida O, Joshi RC, Litsinger JA (1987) Climatic factors affecting the occurrence of insect pests. In: Weather and Rice, Los Banos, Philippines, pp 149-64. 20. Bale JS, Masters GJ, Hodkinson ID, Awmack C, Beze- 
mer TM, Brown VK, Butterfield J, Buse A, et al (2002) Herbivory in global climate change research: direct effects of rising temperature on insect herbivores. Global Change Biol 8, 1-16.

21. Karuppaiah V, Sujayanad GK (2012) Impact of climate change on population dynamics of insect pests. World J Agr Sci 3, 240-6.

22. Anonymous (2002) Effect of Weather Parameters on Insect Pests of Paddy, 31st AGRESCO PPSC Report, Anand, pp 500-1.

23. Netam CS, Dupta AK (2015) Seasonal incidence of rice leaf folder Cnaphalocrocis medinalis (Guen.) in agro climatic condition of Bastar Plateau Zone. Ann Plant Soil Res 17, 24-8.

24. Muhammad S (2009) Integrated management of rice leaf folder, Cnaphalocrocis medinalis (Guenee), (Pyralidae:Lepidoptera) in the Punjab Pakistan. PhD thesis, Univ of Agriculture, Pakistan.

25. Speight MR, Hunter MD, Watt AD (2008) Ecology of Insects: Concept and Applications, Wiley, UK.

26. Khan ZH, Ramamurthy VV (2004) Influence of weather factors on the activity of rice leaf folder Cnaphalocrocis medinalis (Guenee). Ann Plant Protect Sci 12, 263-6.

27. Perfect TJ (1987) Using weather data to forecast insect pest outbreaks. In: Weather and Rice, Los Banos, Philippines, pp 139-47.

28. Grant DB, Chalmers AE, Wolff MA, Hoffman HB, Bushey DF (1998) Fipronil: action at the GABA receptor. Rev Toxicol 2, 147-56.

29. Li X, Huang Q, Yuan J, Tang Z (2007) Fipronil resistance mechanisms in the rice stem borer, Chilo suppressalis Walker. Pestic Biochem Physiol 89, 169-74.

30. Wen ZM, Scott JG (1999) Genetic and biochemical mechanisms limiting fipronil toxicity in the LPR strain of house fly, Musca domestica. Pestic Sci 55, 988-92.

31. Kristensen K, Jespersen JB, Knorr M (2004) Crossresistance potential of fipronil in Musca domestica. Pest Manag Sci 60, 894-900.

32. Mohan M, Gujar GT (2003) Local variation in susceptibility of the diamondback moth Plutella xylostella Lin. to insecticides and role of detoxification enzymes. Crop Protect 22, 495-504.

33. Nugaliyadde L, Ahangama D, Jayathilake K, Wickramasinghe S, Hidaka T (2001) Efficacy of insecticides used for rice leaffolder management in Sri Lanka. Ann Sri Lanka Depart Agr 3, 177-84.

34. Matsumura M, Takeuchi M, Satoh S, Morimura S, Otuka A, Watanabe T, Thanh DV (2009) Current status of insecticide resistance in rice planthoppers in Asia. In: Plant Hoppers: New Treats to the Sustainability of Intensive Rice Production Systems in Asia, Los Banos, Philippines, pp 233-40. 